Björn Hjálmarsson child and adolescent psychiatrist, MA in bioethics Dept. of Child and Adolescent Psychiatry Landspítali-University Hospital

https://doi.org/10.17992//bl.2017.12.162

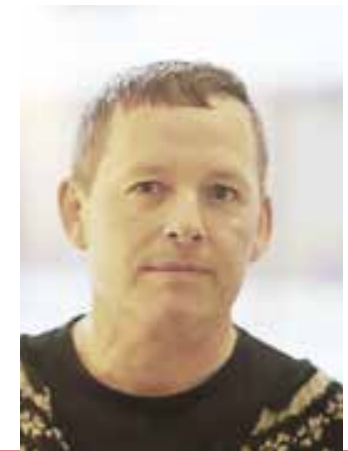

Björn Hjálmarsson

barna- og unglingageðlæknir

barna- og unglingageðdeild Landspítala

\title{
Vaxtarverkir stafrænnar tæknibyltingar
}

Vaxandi framboð á sjónvarpsefni, leikjatölvum, spjaldtölvum, öflugri og öflugri snjalltækjum hefur gjörbreytt lífsmynstri okkar allra. Bandaríski geðlæknirinn Victoria L. Dunckley er meðal brautryðjenda á Vesturlöndum í að gera skipulega grein fyrir pví hvernig yfirdrifinn rafrænn skjátími truflar börn okkar og unglinga. ${ }^{1}$ Samkvæmt tölum Hagstofunnar frá árinu 2014 eru 95\% Íslendinga virkir netnotendur, sem er hærra hlutfall en í öðrum Evrópuríkjum. Fram hefur komið að 83\% menntskælinga kannast við að nota snjallsíma undir stýri og jafnvel að senda textaskilaboð. Í nýlegri könnun á barna- og unglingageðdeild Landspítala kom fram að rafrænn skjátími skjólstæðinga er 5-7 klukkustundir á dag. Flestir foreldrar töldu pennan tíma of langan. Pessar niðurstöður valda áhyggjum pví börn með flókin frávik í taugaproska eða geðræna erfiðleika eru viðkvæmari en önnur börn fyrir truflun af völdum hinna rafrænu skjátækja.

Offitufaraldur geisar á heimsvísu hjá börnum og unglingum. Á Íslandi hefur líkamspyngdarstuðull skólabarna hækkað frá komu sjónvarpsins 1966 pó hægt hafi á vextinum undanfarin ár samkvæmt upplýsingum frá Embætti landlæknis. Svefnraskanir eru algengari en áður og svefnlyfjanotkun barna og unglinga fer mjög vaxandi, kvíði eykst hjá unglingsstúlkum og örorka meðal ungra karlmanna. Ófrjósemi og stoðkerfisvandi vegna einhæfra hreyfinga við skjátækin hafa einnig aukist. Talið er að langur skjátími geti valdið mígreni, flogaköstum og valdið skertri félagsfærni, námsgetu og frammistöðu í starfi. Bandarísku barnalæknasamtökin hafa fylgst grannt með pessari próun og hvatt foreldra til pess að reisa skorður við rafrænum skjátíma barna sinna og unglinga.

Ekki ríkir eining um meinsköpunarferla og greiningarskilmerki fyrir alvarlegan netávana eða netfíkn (internet addiction) en pó er um vaxandi vandamál að ræða á heimsvísu. Mestur er vandinn í austurlöndum fjær par sem hin stafræna bylting reið fyrst í garð. Par líta stjórnvöld á hina stafrænu tæknibyltingu sem orsök meiriháttar lýðheilsuvanda. Samskiptaforrit og margir tölvuleikir eru hannaðir til pess að gefa hraða viðgjöf sem örvar trúlega verðlaunabrautir í heilastofni (ventral tegmental area) sem liggja fram til framheila (nucleus accumbens). Pessar brautir seyta dópamíni og valda vellíðan eða sigurtilfinningu. Yfirdrifin virkjun pessara brauta gæti hugsanlega skýrt hvernig ávani í rafræn skjátæki getur próast. Myndgreiningarrannsóknir af heila, eins og starfræn segulómun, benda til pess að netfíkn skaði heilann og valdi truflun í dópamínefnaskiptum. ${ }^{2}$ Peim mun yngri sem börn eða unglingar byrja að neyta ávana- og fíkniefna pví styttri tími líður til alvarlegs ávana eða fíknar. Trúlega á pað líka við um ávanabindandi notkun rafrænna skjátækja. Í 11. útgáfu greiningarkerfis Alpjóðaheilbrigðisstofnunarinnar (ICD 11, beta draft) er nýr greiningarflokkur sem kallast raskanir vegna fíknihegðunar annarrar en neyslu ávanabindandi efna.

Umdeilt er hvort sú práðlausa örbylgjugeislun sem tengist rafrænum skjátækjum sé hættulaus eða geti hugsanlega valdið heilsutjóni, til dæmis krabbameini í stoðfrumum taugakerfisins (glioma). Práðlaus örbylgjugeislun er ekki nægilega orkumikil til pess að kljúfa rafeindapör en svo virðist sem hún geti truflað andoxunarkerfi frumnanna við að eyða frjálsum róttæklingum. ${ }^{3}$ Sú verkun gæti valdið krabbameinum í peim sem viðkvæmastir eru fyrir pessari tegund geislunar. ${ }^{4}$ Mikla farsímanotkun í 10-15 ár parf til. Tvær alpjóðlegar nefndir hafa komist að ólíkri niðurstöðu hvað petta áhrærir. ICNIRP (International Commission for NonIonizing Radiation Protection) segir práđlausa örbylgjugeislun líklega skaðlausa fyrir utan að hún getur hitað upp vefi. IARC (The International Agency for Research on Cancer) telur práðlausa örbylgjugeislun mögulegan krabbameinsvald í mönnum. Rannsókn par sem rottur voru aldar upp í sambærilegri örbylgjugeislun og farsímar senda frá sér sýndi að karlrottur í rannsóknarhópi fengu sambærileg krabbamein og tengd hafa verið yfirdrifinni farsímanotkun í mannfólki. Engin slík krabbamein fundust í viðmiðunarhópi. $^{5}$

Stafræna tæknibyltingin hefur haft marga kosti i för með sér. Við purfum að læra að umgangast hana af hófstillingu og skynsemi. Yfirdrifinn rafrænn skjátími er nýtt lýðheilsuvandamál. Mikil pörf er á markvissri fræðslu til foreldra svo peir setji börnum sínum hæfileg mörk varðandi notkun rafrænna skjátækja. Skerpa parf á alpjóðlegum öryggisstöðlum gagnvart práðlausri örbylgjugeislun.

\section{Heimildir}

1. Dunckley VL. Reset your's child brain, New World Library, Kaliforníu 2015.

2. Zhu Y, Zhang H, Tian M. Molecular and functional imaging of internet addiction. Biodmed Res Int 2015; 2015: 378675.

3. Havas M. When theory and observation collide: Can non-ionizing radiation cause cancer? Environ Pollut 2017; 222: 501-5.

4. Momoli F, Siemiatycki J, McBride ML, Parent MÉ, Richardson L, Bedard D, et al. Probabilistic Multiple-Bias Modeling Applied to the Canadian Data From the Interphone Study of Mobile Phone Use and Risk of Glioma, Meningioma, Acoustic Neuroma, and Parotid Gland Tumors. Am J Epidemiol 2017; 186: 885-93.

5. Wyde M, Cesta M, Blystone C, Elmore S, Foster P, Hooth M, et al. Report of Partial Findings from the National Toxicology Program Carcinogenesis Studies of Cell Phone Radiofrequency Radiation in Hsd: Sprague Dawley® SD rats (Whole Body Exposures). National Toxiclogy Program 2016, biorxiv.org/content/early/2016/06/23/055699 - nóvember 2017. 